\title{
Efforts to Improve SME Performance through Four Dimensional Analysis of Network Framework Development Entrepreneurship (Study on SMEs in Bekasi)
}

\author{
Alfatih.S.M ${ }^{1 *}$, Munasiron, ${ }^{2}$ Faizal, ${ }^{3}$ \& Nani Aryani ${ }^{4}$ \\ ${ }^{1}$ Economic Faculty of Pembangunan Nasional Veteran University, Indonesia \\ ${ }^{2}$ Economic Faculty of Pembangunan Nasional Veteran University, Indonesia \\ ${ }^{3}$ Economic Faculty of Pembangunan Nasional Veteran University, Indonesia \\ ${ }^{4}$ Economic Faculty of Pembangunan Nasional Veteran University, Indonesia \\ DOI - http://doi.org/10.37502/IJSMR.2021.4705
}

\begin{abstract}
The specific target of this research is to improve the performance of SMEs in Bekasi by implementing an entrepreneurial network model that uses exploratory learning, encouraging efficient use of resources, increasing planning and implementation capacity to overcome complex problems, increasing sources of economic growth, creating jobs, increasing the network of cooperation (networking). Cooperating with business partners and increasing competitiveness, providing better services to clients and customers and not depending on imported products that weaken the people's overall economic resilience. The research method used is to use a hypothesis because this research is all. The research method used is using a hypothesis because this research is an empirical research. Questionnaires will be distributed to 155 SMEs in Bekasi, where these questionnaires are tested for validity and reliability and then processed using PLS (Partial Least Square) so that the accuracy of the analysis tool can be reliable. The results of this study specifically for SMEs in Bekasi are support that the conditional aspects of entrepreneurial networks, a strong relationship between relationships and support for involvement in the external and internal environment are very important and collaborate with reliable human resource capabilities through exploratory learning will be able to improve the performance of SMEs, and this is a part that must be considered in the SME business strategy, so that the business can be sustainable and survive.
\end{abstract}

Keyword: Entrepreneur Network, Explorative Learning, External and Internal Support.

\section{Introduction}

In the development of SMEs, problems are still found, including: weak capital structure and access to sources of capital, availability of raw materials and continuity, limited ability in mastering technology, weak organization and business management, and lack of quantity and quality of human resources. Here a business partnership network is needed between Banking, Government, Universities, Lemlit, and Research Centres to jointly carry out quality improvements and improve the performance of SMEs in the Bekasi area. Several research literatures also found theoretical contradictions, namely the existence of a research gap, others 
stated that network capabilities had no effect on company performance, Batjargal, Bat. (2000). In addition, there are also differences of opinion regarding the Explorative Learning component that has a negative and positive effect on the performance of SMEs, George and Wood (2001), Aldrich (2000). This difference can be explained that network capabilities will not automatically improve company performance, it is possible that there are other influencing factors so that it is possible to need a more appropriate entrepreneurial network model to further explore the management capacity that needs to be possessed by SME owners to be more empowered. SMEs to be more empowered with regard to the ability to build networks (networking). Exploratory learning breakthroughs such as internal training and job training in collaboration with Credit Institutions, Universities, Lemlit, Research Centers, R\&D partnerships to make the quality of human resources in SMEs more skilled and highly dedicated need to be carried out. By looking at the background of the problems above where at the time of the crisis, SMEs were the sector of the people's economy that had the best resilience, which had a strategic role in the country's economic growth, it is necessary to find a solution to all the obstacles that are still experienced by small and medium business units, one alternative solution. It is necessary to create a model for developing entrepreneurial networks and exploratory learning that plays an important role in community economic empowerment activities, especially small people and full implementers of SME product marketing, which will connect SMEs with related parties to improve SME performance and community welfare.

The output target that will be achieved with the entrepreneurial network for SMEs is to obtain an entrepreneurial network model that will be applied to support the improvement of the performance of SMEs which is described by increasing learning capacity through exploratory learning of human resources, encouraging the efficient use of resources, increasing planning and implementation capacity to overcome problems. Complex, increasing sources of economic growth, creating job opportunities, increasing networking in collaboration with business partners and increasing competitiveness. The problem raised in this study is whether the entrepreneurial network model supported by exploratory training will improve the performance of small and medium enterprises in the Bekasi area from a financial and non-financial perspective?

\section{Literature review}

\section{Supporting Research and journals}

To support the success of this research, the researcher looked at several research results from other people's work that had been carried out by several previous researchers, as well as being used as a comparison between the findings of previous research and the findings of the research that the researcher would do. Firmansyah et al's research proves that the quality of entrepreneurship and e-marketing networks can improve the marketing performance of SMEs. Anava Salsa Nur Savitri1 et al showed that Micro, Small and Medium Enterprises were greatly affected by the Covid 19 pandemic. Christopher Yudha Erlangga concluded that the social networking applications that were chosen by many SMEs to market their business products, namely Facebook, Email, Blackberry Messenger (BBM), buying and selling sites, Twitter, personal websites, and other people's sites. 


\section{Supporting Theory}

\section{Entrepreneur Network}

The main challenge for top managers is to create an environment in which people can exploit information in a more effective way; in this case, the main concept is networking. Personal relationship networks are quite effective in communicating complex information, subtle and sensitive signals, and knowledge transfer. Information is data that has met certain requirements to be used as a reference for companies in carrying out their activities. Development of a Network Framework. According to Groen (2005). Development a multidimensional framework that is in accordance with the goals of entrepreneurship research inspired by Parsons' work which explains that there are 4 mechanisms inherent in this definition, namely: Interaction between players Interaction between players includes: Efforts to achieve goals, optimizing processes, and, maintaining patterns culturally structure and provide symbols.

Table 1: Four Dimensions of Network Framework Development

\begin{tabular}{|c|c|c|c|c|}
\hline Dimension & $\begin{array}{l}\text { Relevant } \\
\text { with }\end{array}$ & Capital & Resources & Intervention \\
\hline $\begin{array}{l}\text { Jangkouan } \\
\text { (scope) }\end{array}$ & Strategic goals & $\begin{array}{l}\text { Strategic } \\
\text { Capital }\end{array}$ & $\begin{array}{l}\text { Power, authority, } \\
\text { influence strategic } \\
\text { intensity }\end{array}$ & $\begin{array}{r}\text {-Using power } \\
\text { Redefining } \\
\text { Strategy }\end{array}$ \\
\hline Skala (scale) & $\begin{array}{l}\text { Economic } \\
\text { Optimalization }\end{array}$ & $\begin{array}{l}\text { Economib } \\
\text { Strategy }\end{array}$ & Money & $\begin{array}{l}\text { - Using financial } \\
\text { incentives } \\
\text { Cost Cutting }\end{array}$ \\
\hline $\begin{array}{l}\text { Skills \& } \\
\text { Value }\end{array}$ & $\begin{array}{l}\text { Pemeliharaan } \\
\text { pola dan institusi }\end{array}$ & $\begin{array}{l}\text { Culture } \\
\text { human } \\
\text { capital }\end{array}$ & $\begin{array}{l}\text { Values,Organizat } \\
\text { ion,Knowledge,S } \\
\text { kills,Experience, } \\
\text { Technology }\end{array}$ & $\begin{array}{l}\text { Training \& } \\
\text { Education } \\
\text { Team building } \\
\text { Organizational } \\
\text { system } \\
\text { New Technology }\end{array}$ \\
\hline $\begin{array}{l}\text { Social } \\
\text { networking }\end{array}$ & $\begin{array}{l}\text { Interaction } \\
\text { pattern/process }\end{array}$ & $\begin{array}{l}\text { Social } \\
\text { Capital }\end{array}$ & $\begin{array}{l}\text { Contacts } \\
\text { (multiplex, } \\
\text { structural holes, } \\
\text { cohesive, } \\
\text { equivalent) }\end{array}$ & $\begin{array}{l}\text { - Relationship } \\
\text { management } \\
\text { Structure change } \\
\text { Use of } \\
\text { intermediaries } \\
\text { Supply chain } \\
\text { management }\end{array}$ \\
\hline
\end{tabular}

\section{Company performance}

Companies in measuring their performance are based on the company's financial gains, there are also non-financial ones based on the entrepreneurial process so that they can produce different outcomes on various new dimensions.

\section{Explorative Learning}


Exploratory Learning is an activity that includes internal employee training activities, sharing of skills and knowledge to improve the quality of human resources and products. Here, it is very important to collaborate with business partner training institutions to develop knowledge such as small and large companies, fostered institutions, universities, Lemlit, Research Centers to exchange experiences and research results. Organizations that place more emphasis on responsiveness and knowledge management will improve team learning, and in turn, team learning positively affects task performance and interpersonal relationship quality (Zellmer and Gibson, 2006).

\section{Company performance}

Companies in measuring their performance are based on the company's financial gains, there are also non-financial ones based on the entrepreneurial process so that they can produce different results (outcomes) on various new dimensions. Measuring the performance of small and medium-sized companies has not been well defined, so that in several studies that has been carried out uses many aspects of measurement that are not important. Wiklund (2007) company performance can be seen from the dimensions of growth and is related to finance, which can be related to the company's past performance. For example, sales growth and market growth are traditionally used to measure performance. The second dimension is observing aspects of current company performance events. This relates to non-financial aspects, which are still vital for the company, such as aspects of customer performance. Customer performance here is intended if the entrepreneur has a satisfied and loyal customer base, it is important for the company to remain competitive. The third dimension is seen as an indicator of future-oriented company performance, for example aspects of company innovation. By acting innovatively will lead to competitive advantage where the indicators of innovation involve questions related to the company's ability to develop new products, processes or services.

\section{Theoretical Thinking Framework and Hypotheses}




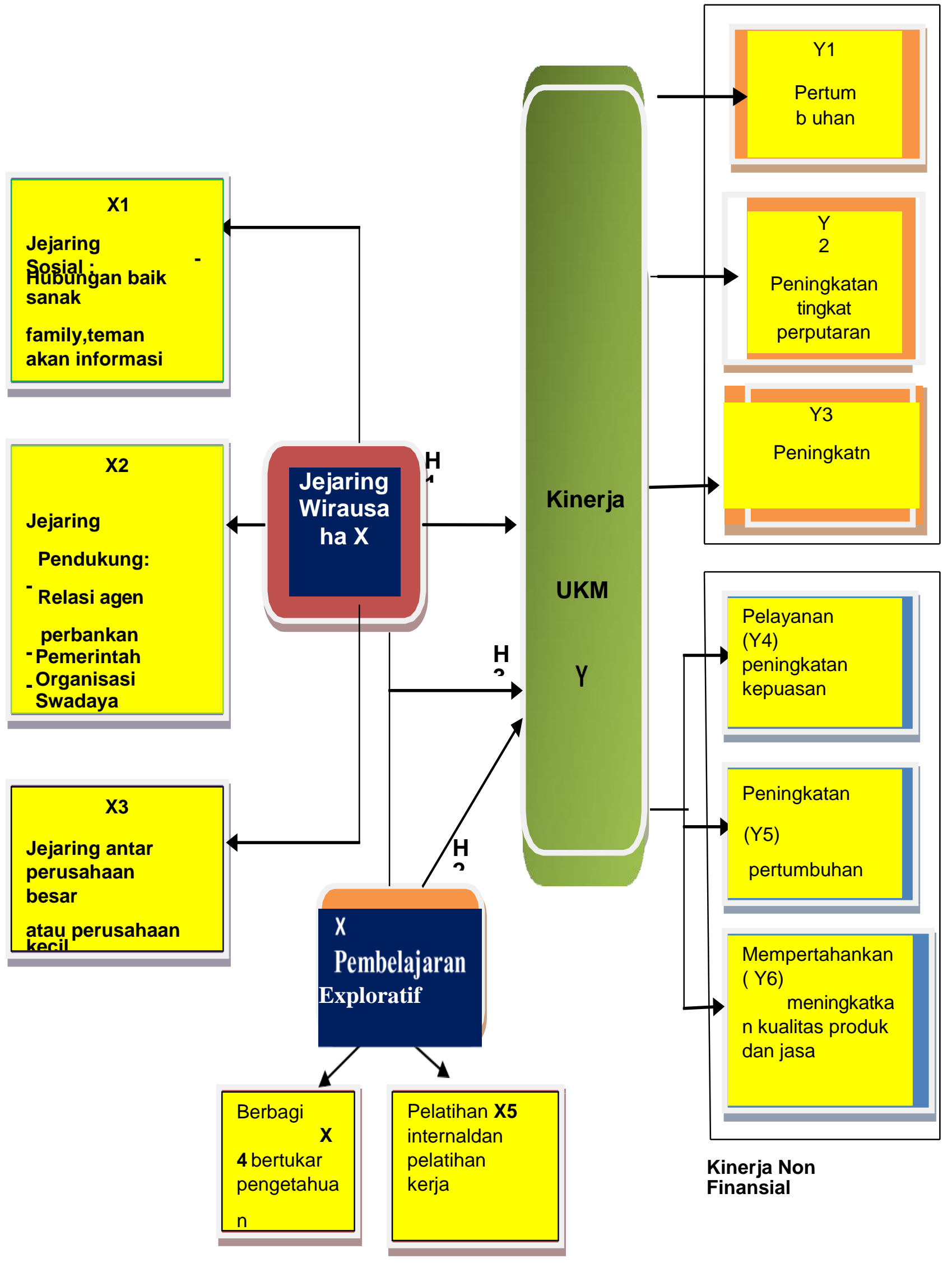

Figure 1 Theoretical Thinking Framework 
H1.A strong entrepreneurial network will improve the performance of SMEs in the Bekasi area. Organizations that place more emphasis on responsiveness and knowledge management will improve team learning, and in turn, team learning positively affects task performance and the quality of interpersonal relationships (Zellmer and Gibson, 2006).

$\mathrm{H} 2$.Strong exploration learning will improve the performance of SMEs in the Bekasi area.

H3.A strong Entrepreneurial Network and Exploration Learning will improve the performance of SMEs in the Bekasi area.

\section{Research Methods}

\section{Types of research}

This research is an empirical research that will test the existing hypothesis. In addition, this study is also a re-examination of the research gap from research conducted by Batjargal, Bat. (2008), George and Wood (2018), Aldrich (2017) which examines the relationship between network capabilities and SME performance. In this study, we examine the design of the entrepreneurial network model whether it is appropriate to be applied to improve the performance of SMEs. The method of gathering power is survey. The instrument is a questionnaire distributed to SMEs from various economic sectors in the Bekasi area.

\section{Data analysis method}

Data were collected using a questionnaire that was first tested for reliability and validity. The test is to determine the consistency and accuracy of the data collected from the use of the instrument. Furthermore, the hypothesis is tested using path analysis or Structural Equation Modeling (SEM) analysis with an alternative method, namely Partial Least Square (PLS), SmartPLS software version 2.0 M3. PLS is a powerful analytical method because it is not based on many assumptions, does not assume the data must be with a certain scale measurement, the number of samples is small, it is appropriate for predictive research in situations of high complexity and low theoretical support.

\section{Results and discussion}

The 2019 SME population is 2,988 SMEs. The results of the questionnaire data that have been distributed have successfully collected 155 questionnaires from the expected 175 questionnaires. The descriptive profiles of respondents and descriptive respondents' answers are explained as follows: 


\begin{tabular}{|l|l|c|}
\hline NO & KLUSTER & JUMLAH UKM \\
\hline 1 & Toko Klontong & 5 \\
\hline 2 & Handmade & 5 \\
\hline 3 & Furniture & 15 \\
\hline 4 & Makanan & 47 \\
\hline 5 & Batu Merah/Batako & 2 \\
\hline 6 & TokoBaju dan Asesoris & 5 \\
\hline 7 & Gorden & 5 \\
\hline 8 & Gypsum & 5 \\
\hline 9 & Konveksi & 5 \\
\hline 10 & Lampus hias & 18 \\
\hline 11 & Minuman & 7 \\
\hline 12 & Property & 5 \\
\hline 13 & Sepatu,sandal & 5 \\
\hline 14 & Jasa & 6 \\
\hline 15 & Souvenir & 155 \\
\hline 16 & Tempe/tahu/kerupuk & \\
\hline & TOTAL & 2 \\
\hline
\end{tabular}

\section{Overview of Respondents Based on Participation in Training Programs}

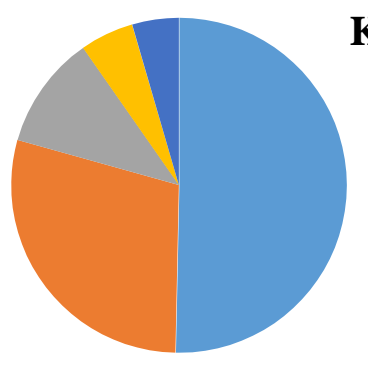

Keikut sertaan

$$
\begin{aligned}
& \text { Jarang } \\
& \text { Kadang } \\
& \text { kadang } \\
& \text { Seringkali } \\
& \text { Selalu } \\
& \text { Tdk pernah }
\end{aligned}
$$

Qualitative findings that can be summarized to describe the condition of the respondent's company performance are shown in Table 2 below: 
Table 2. Description of Respondents' Qualitative Answers Company Performance Variables

\begin{tabular}{|c|c|c|}
\hline Indicator & $\begin{array}{l}\text { Average and } \\
\text { Interpret } \\
\text { station }\end{array}$ & Research Findings - Respondents Perception \\
\hline $\begin{array}{l}\text { Financial Performance : } \\
\text { Striving to increase sales } \\
\text { growth rate (sales } \\
\text { growth) }\end{array}$ & $\begin{array}{r}7.15 \\
\text { High }\end{array}$ & $\begin{array}{l}\text { Total company sales above the industry } \\
\text { average for the last } 3 \text { years. }\end{array}$ \\
\hline $\begin{array}{l}\text { Trying to } \\
\text { increase asset turnover }\end{array}$ & $\begin{array}{r}7.13 \\
\text { High }\end{array}$ & Average company asset turnover rate High \\
\hline $\begin{array}{l}\text { Striving to increase } \\
\text { business profitability }\end{array}$ & $\begin{array}{r}7.23 \\
\text { High }\end{array}$ & $\begin{array}{l}\text { The profitabilityof SME companies has } \\
\text { experienced quite encouraging growth, } \\
\text { especially after there is freedom of choice design, } \\
\text { variety, and modification of SME products. }\end{array}$ \\
\hline $\begin{array}{l}\text { Non-financial } \\
\text { performance: Prioritizing } \\
\text { service to improve } \\
\text { customer satisfaction. }\end{array}$ & $\begin{array}{r}7.56 \\
\text { High }\end{array}$ & $\begin{array}{l}\text { In the last three years, SME owners have } \\
\text { prioritized service to increase customer } \\
\text { satisfaction, so that sales turnover has } \\
\text { increased }\end{array}$ \\
\hline $\begin{array}{l}\text { The growth in the number } \\
\text { of our customers is } \\
\text { experiencing enhancement }\end{array}$ & $\begin{array}{l}7.15 \\
\text { High }\end{array}$ & $\begin{array}{l}\text { Tiga tahun terkhir ini pelanggan kami mengalami } \\
\text { peningkatan karena berbagai alternatif produk } \\
\text { yang disesuaikan dengan } \\
\text { kebutuhan dan kepuasan konsumen. }\end{array}$ \\
\hline $\begin{array}{l}\text { We maintain and improve } \\
\text { product/service quality }\end{array}$ & $\begin{array}{l}7.47 \\
\text { High }\end{array}$ & $\begin{array}{l}\text { In the last three years, SME owners have } \\
\text { prioritized maintaining and improving the quality } \\
\text { of products/services by providing various types or } \\
\text { styles according to the quality and customer } \\
\text { wishes }\end{array}$ \\
\hline
\end{tabular}

\section{Source: Primary data processed}

Description of Respondents' Answers on Exploration/Exploitation Learning Variables

\begin{tabular}{|l|c|c|c|c|c|}
\hline & N & Minimum & Maximum & Mean & Std. Deviation \\
\hline PE 1 & 155 & 4 & 9 & 6,57 & 1.380 \\
PE 2 & 155 & 2 & 9 & 7,32 & 1.262 \\
Valid N (listwise) & 155 & & & & \\
\hline
\end{tabular}

\section{Source: Primary data processed}

Based on the table above, it can be concluded that the respondents' answers ranged from 6.57 to 7.32 with a standard deviation value greater than zero which indicates that the respondents' answers were relatively diverse. The average respondent's answer has an answer that tends to the right. 


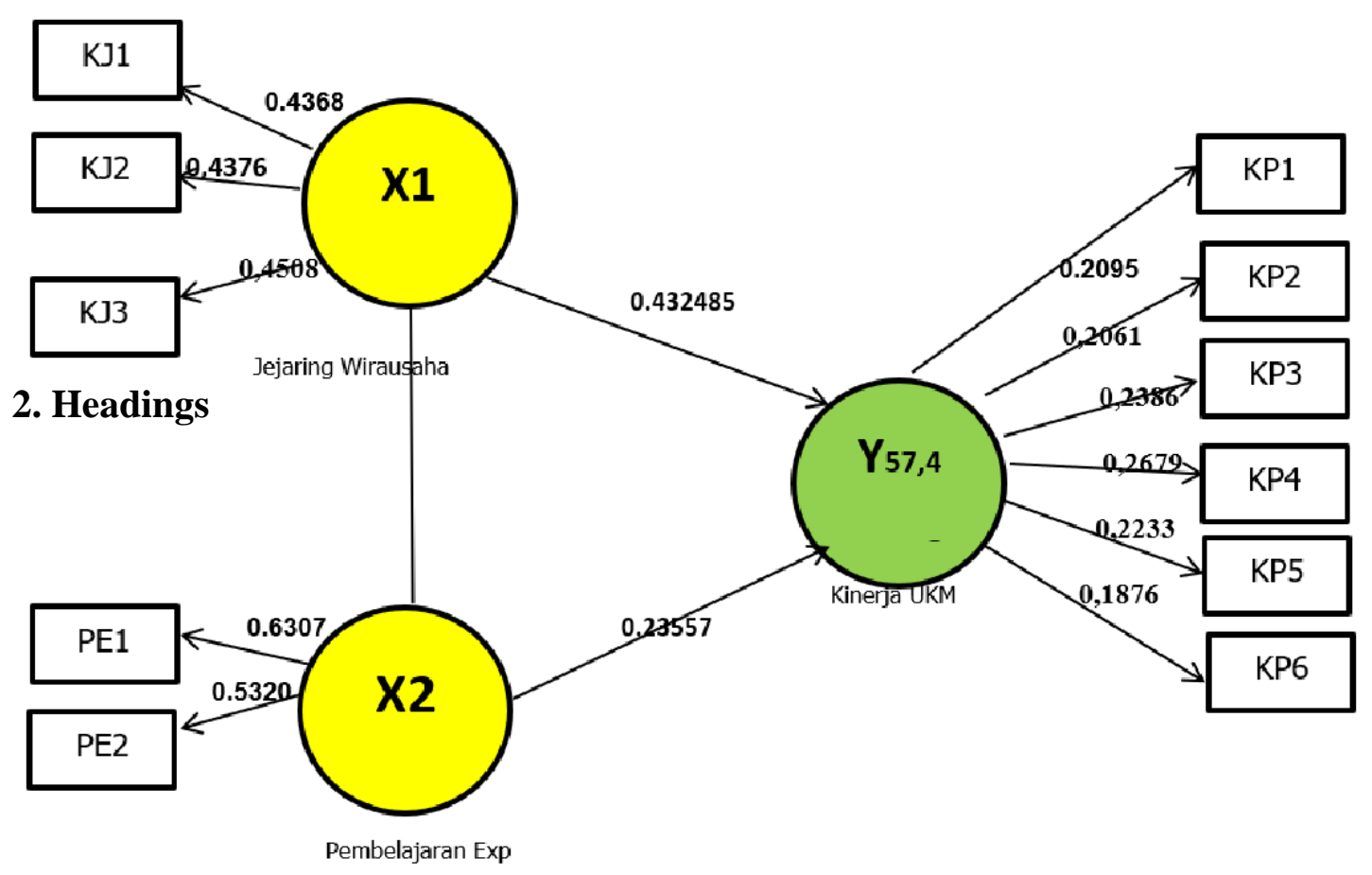

Figure 2: Outer Model Results of All Variables

Table 3. Structural Model Specification

AVE and AVE ROOTS

\begin{tabular}{|c|c|c|}
\hline & AVE & ROOTS AVE \\
\hline Entrepreneur Network & 0.6532 & 0.753451 \\
\hline SME Performance & 0.6875 & 0.841017 \\
\hline Explorative Learning & 0.9255 & 0.925495 \\
\hline
\end{tabular}

\section{AVE ROOTS and Construct Correlation}

Table 4: Composite reliability results that measure the construct.

\begin{tabular}{|l|r|r|l|}
\hline & $\begin{array}{l}\text { Entrepreneur } \\
\text { Network }\end{array}$ & SME Performance & $\begin{array}{l}\text { Explorative } \\
\text { Learning }\end{array}$ \\
\hline Entrepreneur Network & $\mathbf{0 . 7 5 3 4 5 1}$ & & \\
\hline SME Performance & 0.476273 & $\mathbf{0 . 8 4 1 0 1 7}$ & \\
\hline Explorative Learning & 0.511424 & 0.340755 & $\mathbf{0 . 9 2 5 4 9 5}$ \\
\hline
\end{tabular}

Note: The diagonal in bold is the root of AVE 
Table 5: Structural Model Parameter Estimation of All Variables

Path Coefficients (Mean, STDEV, P-Values)

\begin{tabular}{|l|l|l|l|l|r|}
\hline & $\begin{array}{l}\text { Original } \\
\text { Sample } \\
(\mathbf{O})\end{array}$ & $\begin{array}{l}\text { Sample } \\
\text { Mean } \\
(\mathbf{M})\end{array}$ & $\begin{array}{l}\text { Standard } \\
\text { Deviation } \\
\text { (STDEV) }\end{array}$ & $\begin{array}{l}\text { Standard } \\
\text { Error } \\
\text { (STERR) }\end{array}$ & $\begin{array}{l}\text { T Statistics } \\
(\mid \text { O/STERR } \mid)\end{array}$ \\
\hline $\begin{array}{l}\text { Entrepreneur } \\
\text { Network -> } \\
\begin{array}{l}\text { Manager } \\
\text { Performance } \\
\text { SMEs }\end{array}\end{array}$ & $\mathbf{0 . 4 3 2 4 8 5}$ & $\mathbf{0 . 4 3 4 8 5 6}$ & $\mathbf{0 . 0 9 5 4 7 8}$ & $\mathbf{0 . 0 9 5 4 7 8}$ & $\mathbf{4 . 3 8 7 3 5 5}$ \\
\hline $\begin{array}{l}\text { Explorational } \\
\text { Learning -> } \\
\text { SME } \\
\begin{array}{l}\text { Manager } \\
\text { Performance }\end{array}\end{array}$ & $\mathbf{0 . 2 3 5 5 7}$ & $\mathbf{0 . 2 3 3 1 2 3}$ & $\mathbf{0 . 1 2 4 1 1 8}$ & $\mathbf{0 . 1 2 4 1 1 8}$ & $\mathbf{1 . 9 8 5 7 7 3}$ \\
\hline
\end{tabular}

Description: T- statistic sig at $5 \%$

Source: Primary data processed by PLS, 2021

The relationship test between constructs shows that the Entrepreneurial Network construct affects the performance of SMEs by 1,985 at (T count > 1.96) while the Explorative Learning Construct affects the Performance of SMEs by 1,985 at (T count > 1.96) significant at alpha 0.05 . This value can be interpreted that the Entrepreneurial Network and Explorative Learning are variables that positively affect Manager Performance. Overall the first, second, third hypotheses can be accepted.

\section{Discussion}

Hypothesis 1: A strong entrepreneurial network will increase the performance of SMEs in the Bekasi area. It is believed that the increasing number of SME entrepreneurs in Bekasi will contribute to boosting the performance of the national economy. To become a successful entrepreneur, one must have the courage to start a business, focus, and do not enter into fields that are mediocre or have been cultivated by many people. SMEs must enter into a field of business that has not been entered by many others. Even if there is already a business, SMEs must have added value. For example, the products produced are the same, but SMEs have unique packaging, and so on.

Hypothesis 2: Strong exploration learning will improve the performance of SMEs in the Bekasi area. The large number of them and their large role in providing job opportunities for the young people who are generally not highly educated make the overall role of SMEs - especially Micro Enterprises - to the economy is very important. Can we imagine how chaotic Indonesia would be if tens of millions of Micro Business actors suddenly stopped working and employed themselves, and demanded Big Enterprises or the government to give them jobs?

Hypothesis 3: Strong Entrepreneurial Networks and Exploration Learning will improve the performance of SMEs in the Bekasi area a more appropriate entrepreneurial networking model to further explore the management capacity that needs to be possessed 
by SME owners to be more empowered with regard to the ability to build networks (networking). Exploratory learning breakthroughs such as internal training and job training in collaboration with Credit Institutions, Universities, Lemlit, Research Centers, $\mathrm{R} \& \mathrm{D}$ partnerships to make the quality of human resources in SMEs more skilled and highly dedicated need to be carried out.

\section{Conclusions and suggestions}

Based on the results of testing and discussion, the following conclusions can be drawn.

I. Entrepreneurial Networks and Explorative Learning from the test results prove that they greatly contribute to Improving the Performance of SMEs in Bekasi.

II. The results of this study specifically for SMEs in Bekasi are a support that the conditional aspects of entrepreneurial networks, a strong relationship between relationships and support for involvement in the external and internal environment are very important to exist and collaborate with HR capabilities.

III. Entrepreneurship Network Factors and Explorative Learning can only have an impact on Performance. It is possible that there are other factors that will strengthen the development of the model, additional factors that will improve the performance of SMEs so that the optimal model is actually found.

IV. The existing SME business scale is sufficient to get support from family and friends, both non-material and material support.

V. Managers or SME leaders have a very close relationship with their employees and often spend time communicating with them.

\section{Suggestion}

Because the benefits obtained from the Entrepreneurial Network are very high and the research findings found sufficient results from the implementation of the entrepreneurial network, it is recommended to further implement the entrepreneurial networking method which is supported by 3 supporters, namely social networks, supporting networks and inter-company networks.

\section{The managerial implications of this research are:}

I. Small and Medium Enterprises (SMEs) in Bekasi City to be able to observe that the characteristics of entrepreneurs, company characteristics, business and social networks and innovation are able to provide the creation of enterprise upgrading, so that the improvement of these factors becomes the basis that must be met by every SME.

II. Bekasi City itself, with smooth telecommunications and internet access, can actually be optimized for use by existing SMEs. The internet as one of the unlimited information media can be used to access learning networks properly and correctly so that the market picture of the business becomes wider,

III. Small businesses, which are generally family businesses, have a very limited business network so that an efficient and effective business network will be able to spur the growth of SMEs. Optimizing sharing programs with fellow SME actors can be one way to open up the insight of business actors, especially owners, in order to optimize pre-existing competencies.

IV. SMEs in Bekasi City to prioritize product innovation, product innovation, process 
innovation, marketing and organizational innovation as one of the results of the absorptive capacity function that has been implemented so far. With innovation, it can participate in increasing the growth of SMEs.

\section{The agenda for further research is as follows:}

I. This research has provided insight into enterprise upgrading the performance of SMEs in terms of entrepreneurial characteristics, company characteristics, business and social networks, exploratory learning on SME performance in Bekasi city in various types of SME businesses. So that generalizations can be made to industries in other cities. The results of this study can be used as a reference for small industries, which have almost the same characteristics and specifications as Bekasi.

II. This study uses a quantitative descriptive method using Smart PLS. further research needs to be done using more in-depth exploration in order to be able to get better comparison results, especially for the business network model

III. Further research can add other variables in the development of learning models such as cultural factors and the character of business actors or add mediating variables that have not been included in this study.

\section{Reference}

1) Awali, H. (2020). Urgensi Pemanfaatan E-Marketing Pada Keberlangsungan UKM Di Kota Pekalongan Di Tengah Dampak Covid-19. Junal Ekonomi dan Bisnis Islam, 114. Eid, R., \& El-Gohary, H. (2013). The impact of E-marketing use on small business enterprises' marketing success. The Service Industries Journal, 33(1), 31-50. Farida, N., Naryoso,

2) A., \& Yuniawan, A. (2017). Model of Relationship Marketing and E-Commerce in Improving Marketing Performance of Batik SMEs. Jurnal Dinamika Manajemen, 8(1), 20-29. Fahriyah,

3) A., \& Yoseph, R. (2020, July). Keunggulan Kompetitif Spesial sebagai Strategi Keberlanjutan UKM di Era New Normal. In Prosiding Seminar STIAMI (Vol. 7, No. 2, pp. 104- 110).Hardilawati, W. L. (2020). Strategi Bertahan UKM di Tengah Pandemi Covid-19. Jurnal Akuntansi \& Ekonomika, 90- 98.

4) Badan Pusat Statistik. 2017. Laporan perkembangan UKM di Indonesia. Jakarta.

5) Fitriyani, I., Sudiyarti, N., \& Fietroh, M. N. (2020). Strategi Manajemen Bisnis Pasca Pandemi Covid19. Indonesian Journal of Social Sciences and Humanities, 1(2), 87-95.

6) Hardilawati, W. laura. (2020). Strategi Bertahan UKM di Tengah Pandemi Covid-19. Jurnal Akuntansi Dan Ekonomika, 10(1), 89-98. https://doi.org/10.37859/jae.v10i1.1934

7) Hardilawati, W. L.(2019).The Role of Innovation and E-Commerce in Small Business.373,83- 87 Hendrawan, A. (2019). Pengaruh marketing digital terhadap kinerja penjualan produk UKM asti gauri di kecamatan bantarsari cilacaP. Jurnal Administrasi Dan Kesekretarisan, 4(1), 50-61.

8) Hendrawan, A., Sucahyowati, H., Cahyandi, K., Indriyani, \& Rayendra, A. (2019). Pengaruh Marketing Digital Terhadap Kinerja Penjualan Produk UKM Asti Gauri di Kecamatan Bantasari Cilacap. Jurnal Administrasi Dan Kesekretarisan, 4(1), 53-60.

9) Herman. (2020). 2.322 Koperasi dan 185.184 UKM Terdampak Covid-19. Retrieved September10,2020,fromberitasatu.com.website:https://www.beritasatu.com/imanrahman- Vol.1 No.7 Desember 20201437

10) Iddris, F., \& Ibrahim, M. (2015). Examining the relationships between e-Marketing 
adoption and Marketing Performance of Small and Medium Enterprises in Ghana. Journal of Marketing and Consumer Research, 10, 160-169.

11) Kotler, P., \& Armstrong, G. (2014). Principle of Marketing, vol. New Jersey: Pearson Prentice Hall. Kotler,

12) Kumala, R., \& Junaidi, A. (2020). Strategi Bisnis Dan Pemanfaatan Kebijakan Pajak Di Masa Pandemi COVID-19 Dan Era New Normal (Studi Kasus Pelaku UKM Marketplace). Prosiding Seminar Stiami, 7(2), 98-103. Retrieved from http://repositorio.unan.edu.ni/2986/1/5624 .pdf [6

13) Philip dan Amstrong, G. (2012). Principles of Marketing (15th Ed.). Pearson Education Limited Lestari, S. P., \& R, K. A. (2019). The Effect Of Product Quality Toward Interest In. 5(2), 95-102

14) Marlinah, L. (2020). Peluang dan Tantangan UKM Dalam Upaya Memperkuat Perekonomian Nasional Tahun 2020 Ditengah Pandemi Covid 19. Jurnal Ekonomi, 118-124.

15) Masniadi, R., Angkasa, M. A. Z., Karmeli, E., \& Esabella, S. (2020). Telaah Kritis Ketahanan Pangan Kabupaten Sumbawa dalam Menghadapi Pandemi Covid-19. Indonesian Journal of Social Sciences and Humanities, 1(2), 109-120.

16) Narto, G. B. (2020). Penguatan Strategi Pemasaran Pudak Di Tengah Pandemi Covid19 Untuk Meningkatkan Keunggulan Bersaing Usaha Mikro Kecil Menengah Kota Gresik. Jurnal INTECH Teknik Industri, 48-54.

17) Nurhayati, P. (2020). Analisis Pengaruh E-Marketing terhadap Competitive Advantage Melalui Kinerja Marketing. Owner: Riset Dan Jurnal Akuntansi, 4(1), 58-67.

18) Pakpahan, A. K. (2020). COVID-19 dan Implikasi Bagi Usaha Mikro, Kecil, dan Menengah. Purwana, D., Rahmi, R., \& Aditya, S. (2017). Pemanfaatan Digital Marketing Bagi Usaha Mikro,

19) Kecil, Dan Menengah (UKM) Di Kelurahan Malaka Sari, Duren Sawit. Jurnal Pemberdayaan Masyarakat Madani (JPMM), 1(1), 1-17. Shia, B. C., Chen, M.,

20) Pitaloka, H., Al Umar, A. U. A., Hartati, E. R., \& Fitria, D. (2020). The Economic Impact of Covid 19 Outbreak: Evidance from Indonesia. Jurnal Inovasi Ekonomi, 5(3)

21) Ramdansyah, A. D., \& Wang, S. (2015). Comparison of decision making in adopting ecommerce between Indonesia and Chinese Taipei (case study in Jakarta and Taipei City). American Journal of Industrial and Business Management, 5(12), 748.

22) Shofiana, A. (2020). Implementasi Program Afiliasi Berbasis Virtual Team Dalam UKM Sebagai Upaya Peningkatan Perekonomian Pada Masa Pandemi Covid-19 (Implementation Of Virtual Team-Based Affiliation Programs In Msmes As Efforts For Increasing The Economy In The Covid-19 Pandemic Period). Available at SSRN 3590822.

23) Soetjipto, N. (2020). ketahanan UKM Jawa Timur melintasi Pandemi COVID19. Yogyakarta: K- media.

24) Susanti, A., Istiyanto, B., \& Jalari, M. (2020). Strategi UKM pada Masa Pandemi Covid-19 SMEs Strategy at Covid-19 Pandemic SMEs Strategy at Covid-19 Pandemic

25) Sudirjo, F. (2016). Strategi Inovasi Produk Untuk Meningkatkan Kinerja Pemasaran Pada Industri Mebel Skala Menengah Di Jepara. Media Ekonomi Dan Manajemen, 26(2).

26) Sugiri, D. (2020). Menyelamatkan Usaha Mikro, Kecil dan Menengah dari Dampak Pandemi Covid-19. Fokus Bisnis: Media Pengkajian Manajemen Dan Akuntansi, 19(1), 76-86. https://doi.org/10.32639/fokusbisnis.v19i1 .575

27) Tripayana, S., \& Pramono, J. (2020). Kualitas Produk, Pelayanan, dan Loyalitas Pelanggan Dimana Kepuasan Sebagai Variabel Intervening pada UKM Start Up Pariwisata Kombuchi Brewing Co, Bali. Jemap, 2(2), 182. Journal of Education, 
Humaniora and Social Sciences (JEHSS) ISSN2622-3740 (Online) Vol 3, No. 3, April 2021: $\quad 1113 \quad-1123 \quad$ http://mahesainstitute.web.id/ojs2/index.php/jehss mahesainstitut@gmail.com 1123 this work is licensed under a Creative Commons Attribution 4.

28) Utaminingsih, A. (2016). Pengaruh orientasi pasar, inovasi, dan kreativitas strategi pemasaran terhadap kinerja pemasaran pada UKM kerajinan rotan di desa Teluk Wetan, Welahan, Jepara. Media Ekonomi Dan Manajemen, 31(2). LINK SUMBER http://bekasikab.go.id/berita-881-dinas-koperasi-UKM-apresiasi-gerakan-

kewirausahaan-nasional-.html\#ixzz75IWewKwFUnder

Creative

Commons

License: Attribution Non-Commercial No Derivatives 